\title{
Prawne otoczenie dla inwestycji zagranicznych w Polsce
}

Swoboda przepływu kapitału oraz szeroko rozumianych dóbr i usług realizowana jest przez państwa za pomocą szeregu instrumentów prawnych, wyznaczających stopień otwarcia gospodarki danego kraju dla uczestnictwa w niej podmiotów zagranicznych, a szczególnie możliwości podejmowania i prowadzenia przez te podmioty działalności gospodarczej, zatrudnienia, dokonywania inwestycji, obrotu nieruchomościami, obrotu dewizowego. Kształt przepisów prawnych tworzących ramy normatywne dla aktywności gospodarczej inwestorów zagranicznych $w$ danym kraju jest elementem definiującym stopień dostępu do danego rynku, poziom jego internacjonalizacji i liberalizacji. Celem niniejszego artykułu jest analiza regulacji prawa polskiego w zakresie warunków prawnych podjęcia i wykonywania działalności gospodarczej na terytorium Rzeczpospolitej Polskiej przez osoby zagraniczne i przedsiębiorców zagranicznych. Temat ten jest szczególnie aktualny w związku ze zmianami wprowadzonymi w tym obszarze przez obowiązującą od niedawna Konstytucję Biznesu.

Słowa kluczowe: osoba zagraniczna, przedsiębiorca zagraniczny, działalność gospodarcza, transgraniczna działalność usługowa, Konstytucja Biznesu.

\section{Uwagi wprowadzające}

Zjawisko swobodnego przepływu produktów, technologii, kapitału oraz przemieszczania się instytucji, przedsiębiorców i ludzi jest elementem charakterystycznym i pozostającym w ścisłym związku z postępującym procesem umiędzynarodowienia stosunków społeczno-gospodarczych na płaszczyźnie rynków, branż i przedsiębiorstw. Konsekwencją działania rynku w skali globalnej jest zmniejszenie barier w gospodarce światowej, w szczególności w handlu międzynarodowym, ale także stopniowe znoszenie ograniczeń w przepływie kapitału i zasobów finansowych. W tym kontekście zniesienie przeszkód dla bezpośrednich inwestycji zagranicznych tak, aby podmioty zagraniczne konkurowały z krajowymi na równych zasadach stanowi jedną z głównych tendencji występujących w gospodarce światowej (Nowak, 2017, s. 19-20; Kotyński, 2005, s. 9 i nast.; Hejduk i Bakalarczyk, 2013, s. 11 i nast.). Dzięki procesowi globalizacji oraz traktatom międzynarodowym w obszarze wolnego handlu państwa otwie- 
rają się na wymianę handlową oraz inwestycje zagraniczne, a zasada wolnego handlu stanowi jedną z podstaw działania Unii Europejskiej (Nowak, 2017a, s. 27). Zgodnie z preambułą dyrektywy Parlamentu Europejskiego i Rady dotyczącej usług na rynku wewnętrznym (Dz. Urz. UE L 276 z 27.12.2006), Unia Europejska dąży do tworzenia coraz ściślejszych związków między państwami i narodami Europy oraz do zapewnienia postępu gospodarczego i społecznego. Zgodnie z postanowieniami Traktatu ustanawiającego Wspólnotę Europejską ${ }^{1}$ rynek wewnętrzny obejmuje obszar bez granic wewnętrznych, w którym zapewniony jest swobodny przepływ usług, swoboda przedsiębiorczości oraz swoboda świadczenia usług wewnątrz Wspólnoty. Konkurencyjny rynek usług ma istotne znaczenie przy wspieraniu wzrostu gospodarczego i tworzeniu miejsc pracy w Unii Europejskiej. W preambule stwierdza się ponadto, że obecnie liczne bariery na rynku wewnętrznym uniemożliwiają usługodawcom, w szczególności małym i średnim przedsiębiorstwom, rozszerzanie swojej działalności poza granice ich krajów i pełny udział w korzyściach z rynku wewnętrznego. Osłabia to globalną konkurencyjność usługodawców z Unii Europejskiej. Wolny rynek zobowiązujący państwa członkowskie do znoszenia ograniczeń w transgranicznym świadczeniu usług, przy jednoczesnej większej przejrzystości oraz pełniejszej informacji, oznaczałby dla konsumentów większy wybór i lepszą jakość usług po niższych cenach ${ }^{2}$.

Zwiększanie skali międzynarodowych obrotów usługami jest efektem zintensyfikowanych w czasie globalizacji procesów deregulacyjnych, postępu technicznego oraz wzrostu liczbowego klasy średniej w krajach o gospodarkach wschodzących i krajach rozwijających się (Budnikowski, 2017, s. 29). Proces globalizacji oznacza wejście w nową jakościowo fazę umiędzynarodowienia działalności gospodarczej, realizowaną na płaszczyźnie rynków, sektorów i przedsiębiorstw (Budnikowski, 2017, s. 599), a z perspektywy internacjonalizacji obrotów gospodarczych podstawowe znaczenie posiada kwestia zniesienia barier dla inwestycji zagranicznych w danym kraju, pozwalających zmniejszać międzynarodowe dysproporcje w wyposażeniu w kapitał. Inwestycje zagraniczne, choć nie wpływają w jednakowy sposób na wszystkie mierniki koniunktury gospodarczej, stanowią jednak jeden z motorów wzrostu gospodarczego, przyczyniając się do powiększenia zasobów kapitału danej gospodarki, co wiąże się ze wzrostem produkcyjności i płac oraz zwiększenia dostępności do nowoczesnych technologii (Mankiw i Taylor, 2016, s. 80; Burda i Wyplosz, 2013, s. 171; Begg, Vernasca, Fischer i Dornbusch, 2014,

Obecnie Traktatu o funkcjonowaniu Unii Europejskiej (TFUE).

2 Dyrektywa 2006/123/WE Parlamentu Europejskiego i Rady z dnia 12 grudnia 2006 r. dotycząca usług na rynku wewnętrznym (Dz.Urz. UE L 276 z 27.12.2006), zwana również dyrektywą usługową. 
s. 480 i nast.). Warto również zaznaczyć rolę zwiększania inwestycji zagranicznych i kapitału obcego jako instrumentu wychodzenia ze światowego kryzysu finansowego w gospodarkach światowych ostatnich lat (Nowak, 2015, s. 590).

Swoboda przepływu szeroko rozumianych usług jest realizowana przez państwa za pomocą szeregu instrumentów prawnych, wyznaczających stopień otwarcia gospodarki danego kraju dla uczestnictwa w niej podmiotów zagranicznych (szerzej o podmiotach gospodarki światowej zob. Orłowska i Żołądkiewicz, 2012, s. 42 i nast.), w szczególności możliwości podejmowania i prowadzenia przez te podmioty działalności gospodarczej, możliwości zatrudnienia, dokonywania inwestycji, obrotu nieruchomościami, obrotu dewizowego (Budnikowski, 2017, s. 36). Kształt przepisów prawnych tworzących ramy normatywne dla wykonywania działalności gospodarczej w danym kraju przez przedsiębiorców zagranicznych jest elementem definiującym stopień dostępu do danego rynku, poziom jego internacjonalizacji i liberalizacji. Wyznaczone przez normodawcę ramy regulacyjne stanowią podstawę dla ekonomicznej analizy gospodarki oraz ustalają kierunki polityki gospodarczej państwa w tym zakresie.

\section{Konstytucja Biznesu}

W dniu 30 kwietnia 2018 r. wszedł w życie pakiet ustaw określanych jako Konstytucja Biznesu, przeprowadzających gruntowną reformę polskiego prawa gospodarczego. Zmiany wprowadzone przez Konstytucję Biznesu stanowią najgłębszą i najbardziej kompleksową po 1989 roku rekonstrukcję otoczenia gospodarczego, w którym funkcjonuje przedsiębiorca na polskim rynku. Celem reformy jest poprawa warunków prawno-instytucjonalnych, w których działają przedsiębiorcy poprzez urzeczywistnienie konstytucyjnej zasady wolności gospodarczej oraz stworzenie partnerskich relacji przedsiębiorca - państwo (zasada „co nie jest przez prawo zakazane jest dozwolone”, klauzula pewności prawa, reguła domniemania uczciwości przedsiębiorcy, rozstrzygania wątpliwości faktycznych na jego korzyść, przyjazna interpretacja przepisów prawa, zasada rozstrzygania wątpliwości prawnych na korzyść przedsiębiorcy, reguła pogłębiania zaufania, proporcjonalności, bezstronności i równego traktowania, czy wreszcie zasada odpowiedzialności urzędników za naruszenie prawa, pewności prawa i przewidywalności rozstrzygnięć organów państwa, współdziałania organów w celu pełnego wyjaśnienia sytuacji przedsiębiorcy, odformalizowanie komunikacji między urzędem a przedsiębiorcą). Celem Konstytucji Biznesu jest również wsparcie przedsiębiorczości, w tym stworzenie przyjaznych warunków 
prawnych do rozpoczynania działalności gospodarczej, zmniejszenie tzw. szarej strefy, zapewnienie wsparcia instytucjonalnego dla przedsiębiorców poprzez powołanie Rzecznika Małych i Średnich Przedsiębiorców. Główną osią zmian jest nowa ustawa - Prawo przedsiębiorców ${ }^{3}$, zastępująca dotąd obowiązującą ustawę o swobodzie działalności gospodarczej ${ }^{4}$. Nowa ustawa w sposób systemowy określa podstawy ustroju gospodarczego Polski, stanowiąc zbiór fundamentalnych zasad obrotu gospodarczego, określa pozycję prawną przedsiębiorcy oraz obowiązki państwa wobec przedsiębiorców. Szczegółowe zmiany wprowadzone ustawą - Prawo przedsiębiorców były szeroko opisywane, wśród nich na szczególną uwagę zasługują uproszczenia dla drobnej działalności i osób dopiero organizujących działalność gospodarczą. Drobna działalność zarobkowa będzie mogła być prowadzona w sposób wolny, bez konieczności wpisu do CEIDG, osoba ją wykonująca nie będzie otrzymywała numeru Regon. Osoby fizyczne rozpoczynające wykonywanie działalności gospodarczej zwolnione są z obowiązku odprowadzania składek na ubezpieczenie społeczne przez 6 miesięcy. Ustawa wprowadza uproszczenia w zakresie reglamentacji działalności gospodarczej. Dotychczasowe zgody i licencje, jako oddzielne formy reglamentacji, przestają istnieć. Pozostają trzy formy ograniczeń: działalność wymagająca koncesji, działalność wymagająca zezwolenia i działalność regulowana. Istotne są również zmiany ograniczające kontrolę działalności gospodarczej.

Konstytucja Biznesu, poza nową ustawą - Prawo przedsiębiorców, obejmuje również: ustawę o Rzeczniku Małych i Średnich Przedsiębiorców5; ustawę o Centralnej Ewidencji i Informacji o Działalności Gospodarczej i Punkcie Informacji dla Przedsiębiorcy6; ustawę - Przepisy wprowadzające; ustawę - Prawo przedsiębiorców; inne ustawy dotyczące działalności gospodarczej ${ }^{7}$ oraz - co jest kluczowe z punktu widzenia przedmiotu niniejszej analizy - ustawę o zasadach uczestnictwa przedsiębiorców zagranicznych i innych osób zagranicznych w obrocie gospodarczym na terytorium Rzeczypospolitej Polskiej

3 Ustawa z dnia 6 marca 2018 r. - Prawo przedsiębiorców (Dz.U. 2018, poz. 646).

4 Ustawa z dnia 2 lipca 2004 r. o swobodzie działalności gospodarczej (t.j. Dz.U. 2017, poz. 2168 z późn.zm.), uchylona ustawą z dnia 6 marca 2018 r. - Przepisy wprowadzające ustawę - Prawo przedsiębiorców oraz inne ustawy dotyczące działalności gospodarczej (Dz.U. 2018, poz. 650).

5 Ustawa z dnia 6 marca 2018 r. o Rzeczniku Małych i Średnich Przedsiębiorców (Dz.U. 2018, poz. 648).

6 Ustawa z dnia 6 marca 2018 r. o Centralnej Ewidencji i Informacji o Działalności Gospodarczej i Punkcie Informacji dla Przedsiębiorcy (Dz.U. 2018, poz. 647 z późn. zm.).

7 Ustawa z dnia 6 marca 2018 r. - Przepisy wprowadzające ustawę - Prawo przedsiębiorców oraz inne ustawy dotyczące działalności gospodarczej (Dz.U. 2018, poz. 650).

8 Ustawa z dnia 6 marca 2018 r. o zasadach uczestnictwa przedsiębiorców zagranicznych i innych osób zagranicznych w obrocie gospodarczym na terytorium Rzeczypospolitej Polskiej (Dz.U. 2018, poz. 649 z późn. zm.). 
Dotychczasowe zasady dotyczące działalności gospodarczej osób zagranicznych na terytorium RP rozproszone były w kilku aktach prawnych. Zastosowana technika legislacyjna powodowała w efekcie brak przejrzystości odnośnie do kluczowych warunków funkcjonowania przedsiębiorców zagranicznych w krajowym obrocie gospodarczym. Warunki te określone były ustawą o swobodzie działalności gospodarczej, ustawą o świadczeniu usług na terytorium Rzeczypospolitej Polskiej ${ }^{9}$, ustawą o zasadach prowadzenia na terytorium Polskiej Rzeczypospolitej Ludowej działalności gospodarczej w zakresie drobnej wytwórczości przez zagraniczne osoby prawne i fizyczne ${ }^{10}$. Nowa ustawa o zasadach uczestnictwa przedsiębiorców zagranicznych i innych osób zagranicznych w obrocie gospodarczym na terytorium Rzeczypospolitej Polskiej (dalej: ustawa) scala w jednym akcie prawnym obowiązujące dotychczas regulacje prawne, w sposób kompleksowy i spójny ustalając warunki uczestnictwa przedsiębiorców zagranicznych w obrocie gospodarczym w Polsce. Powyższe powoduje, że zasady te stają się przejrzyste, bardziej przystępne i zrozumiałe dla podmiotów zagranicznych zainteresowanych dokonywaniem inwestycji na terytorium Polski. Omawiana ustawa w zakresie swojej regulacji wdraża dyrektywę 2006/123/WE Parlamentu Europejskiego i Rady dotyczącą usług na rynku wewnętrznym.

\section{Zasady wykonywania działalności gospodarczej na terytorium RP przez osoby zagraniczne oraz przedsiębiorców zagranicznych}

\subsection{Formy organizacyjnoprawne oraz warunki wykonywania działalności gospodarczej}

Osoby zagraniczne z państw członkowskich Unii Europejskiej lub państw członkowskich Europejskiego Porozumienia o Wolnym Handlu (EFTA) - strony umowy o Europejskim Obszarze Gospodarczym (państwa członkowskie) moga podejmować i wykonywać działalność gospodarczą na terytorium RP na takich

9 Ustawa z dnia 4 marca 2010 r. o świadczeniu usług na terytorium Rzeczypospolitej Polskiej (t.j. Dz.U. 2016, poz. 893 z późn.zm.), uchylona ustawą z dnia 6 marca 2018 r. - Przepisy wprowadzające ustawę - Prawo przedsiębiorców oraz inne ustawy dotyczące działalności gospodarczej (Dz.U. 2018, poz. 650).

10 Ustawa z dnia 6 lipca 1982 r. o zasadach prowadzenia na terytorium Polskiej Rzeczypospolitej Ludowej działalności gospodarczej w zakresie drobnej wytwórczości przez zagraniczne osoby prawne i fizyczne (t.j. Dz.U. 1989, poz. 27 z późn.zm.), uchylona ustawą z dnia 6 marca 2018 r. - Przepisy wprowadzające ustawę - Prawo przedsiębiorców oraz inne ustawy dotyczące działalności gospodarczej (Dz.U. 2018, poz. 650). 
samych zasadach, jak obywatele polscy. Przez osobę zagraniczną rozumie się osobę fizyczną nieposiadającą obywatelstwa polskiego, osobę prawną z siedzibą za granicą oraz jednostkę organizacyjną niebędącą osobą prawną posiadającą zdolność prawną, z siedzibą za granicą. Regułą tą objęte są podmioty prawa, bez względu na ich status prawnogospodarczy w państwie członkowskim.

Podobna zasada dotyczy obywateli innych państw niż państwa członkowskie, jeśli spełniają warunki określone w art. 4 ust. 2 ustawy (w szczególności jeśli posiadają zezwolenie na pobyt stały na terytorium RP, zezwolenie na pobyt rezydenta długoterminowego UE, zezwolenie na pobyt czasowy udzielony na wskazanych zasadach, status uchodźcy, ochronę uzupełniającą, korzystają w RP z ochrony czasowej, posiadają ważną Kartę Polaka i in.).

Pozostałe osoby zagraniczne mogą podejmować i wykonywać działalność gospodarczą na terytorium RP wyłącznie w formie spółki komandytowej, komandytowo-akcyjnej, z ograniczoną odpowiedzialnością i akcyjnej. Mogą również przystępować do takich spółek oraz obejmować bądź nabywać ich udziały lub akcje, o ile umowy międzynarodowe nie stanowią inaczej. Należy przy tym podkreślić, iż wymienione spółki są podmiotami prawa polskiego, działającymi w oparciu o przepisy prawa polskiego. Ustawa wyklucza możliwość podejmowania i wykonywania przez tę kategorię osób zagranicznych działalności gospodarczej na terytorium RP w innej formie organizacyjnoprawnej, np. w formie spółki jawnej czy partnerskiej oraz przystępowania do takich podmiotów.

Warto przy tym pamiętać, że nabycie lub objęcie przez cudzoziemca udziałów lub akcji w spółce handlowej z siedzibą na terytorium RP, a także każda inna czynność prawna dotycząca udziałów lub akcji wymaga zezwolenia ministra właściwego do spraw wewnętrznych, jeżeli w ich wyniku spółka będąca właścicielem lub użytkownikiem wieczystym nieruchomości na terytorium RP stanie się spółką kontrolowaną. Jeśli spółka handlowa z siedzibą na terytorium RP, będąca właścicielem lub użytkownikiem wieczystym nieruchomości na terytorium RP, jest spółką kontrolowaną, a udziały lub akcje nabywa lub obejmuje cudzoziemiec niebędący udziałowcem lub akcjonariuszem, to czynność taka również wymaga zezwolenia ministra właściwego do spraw wewnętrznych. Powyższa regulacja wynika $\mathrm{z}$ obowiązującej w prawie polskim zasady wymagającej zezwolenia ministra właściwego do spraw wewnętrznych na nabycie przez cudzoziemca prawa własności nieruchomości lub prawa użytkowania wieczystego, na podstawie każdego zdarzenia prawnego ${ }^{11}$. W rozumieniu ustawy o nabywaniu nieruchomości przez cudzoziemców, cudzoziemcem jest osoba fizyczna nieposiadająca obywatelstwa polskiego, osoba prawna mająca siedzibę

11 Ustawa z dnia 24 marca 1920 r. o nabywaniu nieruchomości przez cudzoziemców (t.j. Dz.U. 2017, poz. 2278). 
za granicą, nieposiadająca osobowości prawnej spółka w/w osób, mająca siedzibę za granicą, utworzona zgodnie z ustawodawstwem państw obcych oraz osoba prawna i spółka handlowa nieposiadająca osobowości prawnej mająca siedzibę na terytorium RP, kontrolowana bezpośrednio lub pośrednio przez osoby lub spółki wyżej wymienione. Ustawa o nabywaniu nieruchomości przez cudzoziemców zawiera szereg wyłączeń od obowiązku uzyskania zezwolenia, spośród których największe znaczenie posiada zwolnienie z wymogu uzyskania zezwolenia przez cudzoziemców będących obywatelami lub przedsiębiorcami państw - stron umowy o Europejskim Obszarze Gospodarczym albo Konfederacji Szwajcarskiej.

Przedsiębiorcy zagraniczni z państw członkowskich (a więc osoby zagraniczne wykonujące działalność gospodarczą w państwie członkowskim) mogą na terytorium RP tworzyć oddziały. Oddział tworzony jest wyłącznie dla wykonywania działalności gospodarczej na terytorium RP w zakresie, w jakim przedsiębiorca zagraniczny prowadzi tę działalność za granicą. Przedsiębiorcy zagraniczni z innych państw niż państwa członkowskie mogą tworzyć oddziały na zasadzie wzajemności, o ile ratyfikowane umowy międzynarodowe nie stanowią inaczej. Oddział przedsiębiorcy zagranicznego podlega rejestracji w Rejestrze Przedsiębiorców Krajowego Rejestru Sądowego.

Utrzymana została dotychczasowa zasada braku odrębnej podmiotowości prawnej oddziału przedsiębiorcy zagranicznego w świetle przepisów prawa polskiego. Oddział stanowi zatem wyodrębnioną i samodzielną organizacyjnie część działalności gospodarczej wykonywanej przez przedsiębiorcę zagranicznego i działa on w ramach podmiotowości prawnej samego przedsiębiorcy zagranicznego. $\mathrm{Z}$ tego powodu przepisy prawa wymagają, aby przedsiębiorca zagraniczny tworzący oddział na terytorium RP ustanowił osobę upoważnioną w oddziale do reprezentowania przedsiębiorcy zagranicznego. Zgodnie z art. 39 pkt 4 ustawy o Krajowym Rejestrze Sądowym ${ }^{12}$, osoba upoważniona przez przedsiębiorcę zagranicznego do reprezentowania go w oddziale musi być ujawniona w rejestrze przedsiębiorców.

Nowa regulacja ograniczyła obowiązek przeprowadzenia postępowania likwidacyjnego w trybie i na zasadach określonych w przepisach kodeksu spółek handlowych o likwidacji spółki z o.o. tylko do sytuacji, gdy likwidacja oddziału przedsiębiorcy zagranicznego następuje w wyniku wydania przez właściwego ministra decyzji o zakazie wykonywania działalności gospodarczej przez przedsiębiorcę zagranicznego w ramach oddziału. Określona w ustawie procedura wydania przez właściwego ministra decyzji o zakazie wykonywania działalności

12 Ustawa z dnia 20 sierpnia 1997 r. o Krajowym Rejestrze Sądowym (t.j. Dz.U. 2018, poz. 986 z późn. zm.). 
gospodarczej przez przedsiębiorcę zagranicznego w formie oddziału nie dotyczy przedsiębiorców zagranicznych państw członkowskich. W przypadku gdy przedsiębiorca zagraniczny samodzielnie podejmuje decyzję o likwidacji oddziału, wówczas - w przeciwieństwie do dotychczas obowiązujących regulacji - nie ma obowiązku przeprowadzenia postępowania likwidacyjnego w trybie i na zasadach określonych w kodeksie spółek handlowych o likwidacji spółki z o.o.

Przedsiębiorca zagraniczny może tworzyć na terytorium RP przedstawicielstwa, których zakres działania obejmuje wyłącznie prowadzenie działalności w zakresie reklamy i promocji przedsiębiorcy zagranicznego. Przedstawicielstwo nie może służyć do wykonywania działalności gospodarczej przez przedsiębiorcę zagranicznego na terytorium Polski. Utworzenie i prowadzenie przedstawicielstwa wymaga wpisu do rejestru przedstawicielstw przedsiębiorców zagranicznych. Co istotne, wpis do rejestru dokonywany jest na okres 2 lat od dnia dokonania wpisu, na wniosek przedsiębiorcy zagranicznego wpis zostaje wydłużony na kolejny okres 2 lat.

Na marginesie należy dodać, że ustawa o zasadach uczestnictwa przedsiębiorców zagranicznych i innych osób zagranicznych w obrocie gospodarczym na terytorium Rzeczypospolitej Polskiej, choć mająca wymiar regulacji kompleksowej i scalającej rozproszone dotychczas przepisy prawa, nie jest wyłącznym źródłem prawa określającym organizacyjnoprawne warunki działalności podmiotów zagranicznych w polskim obrocie gospodarczym. Poza jej zakresem znajdują się np. przepisy określające procedury transgranicznego łączenia się spółek kapitałowych i komandytowo-akcyjnych (regulowane przepisami kodeksu spółek handlowych ${ }^{13}$ ).

\subsection{Transgraniczna działalność usługowa}

Ustawa o zasadach uczestnictwa przedsiębiorców zagranicznych i innych osób zagranicznych w obrocie gospodarczym na terytorium RP inkorporuje przepisy określające warunki wykonywania transgranicznej działalności usługowej. Kluczową kwestią z punktu widzenia tej regulacji jest pojęcie „usługi”, definiowane w art. 3 pkt 8 ustawy jako świadczenie wykonywane przez usługodawcę z państwa członkowskiego na własny rachunek, zwykle za wynagrodzeniem, w szczególności usługi budowlane, handlowe oraz usługi świadczone w ramach wykonywanego zawodu. Pomijając fakt, że definicja ta obarczona jest błędem logicznym idem per idem (usługą są (...) usługi), jej brzmienie skłania do kilku spostrzeżeń. Przede wszystkim ustalenia wymaga jej zakres przedmio-

13 Ustawa z dnia 15 września 2000 r. - Kodeks spółek handlowych (t.j. Dz.U. 2017, poz. 1577 z późn. zm.). 
towy, a więc określenie do jakiego rodzaju aktywności gospodarczej odnoszą się analizowane przepisy ustawy. Definicja usługi, zawarta w ustawie, swoim brzmieniem nawiązuje do pojęcia „usługi” zawartego w art. 57 Traktatu o funkcjonowaniu Unii Europejskiej, zgodnie z którym usługami są świadczenia wykonywane zwykle za wynagrodzeniem w zakresie, w jakim nie są objęte postanowieniami o swobodnym przepływie towarów, kapitału i osób. Zgodnie z art. 57 TFUE, usługi obejmują zwłaszcza: działalność o charakterze przemysłowym, działalność o charakterze handlowym oraz wykonywanie wolnych zawodów. Zgodnie natomiast $\mathrm{z}$ art. 4 pkt 1 dyrektywy usługowej usługa oznacza wszelką działalność gospodarczą prowadzoną na własny rachunek, zwykle świadczoną za wynagrodzeniem, zgodnie z art. 50 Traktatu. Regulacje unijne dają więc podstawę dla szerokiego rozumienia pojęcia „usługi” jako działalności gospodarczej w szczególności o charakterze przemysłowym, handlowym oraz wykonywanie wolnych zawodów. Polski ustawodawca, formułując definicję usługi, również posługuje się jedynie przykładowym wyliczeniem rodzajów aktywności gospodarczych, klasyfikowanych do tej kategorii pojęciowej. Katalog ten nie ma więc charakteru zamkniętego, natomiast jego normatywne dekodowanie musi być przeprowadzane $\mathrm{z}$ uwzględnieniem licznych wyłączeń określonych w art. 12 ustawy (odnoszących się do szczególnych kategorii aktywności gospodarczych, do których przepisy ustawy nie mają zastosowania).

Usługodawca z państwa członkowskiego może czasowo świadczyć usługi na terytorium RP na zasadach określonych w przepisach TFUE albo w postanowieniach umów regulujących swobodę świadczenia usług, bez konieczności uzyskania wpisu do rejestru przedsiębiorców w Krajowym Rejestrze Sądowym albo Centralnej Ewidencji i Informacji o Działalności Gospodarczej. Usługodawcą jest przedsiębiorca zagraniczny z państwa członkowskiego, który wykonuje działalność gospodarczą zgodnie z obowiązującymi w tym państwie przepisami, a na terytorium RP czasowo oferuje lub świadczy usługę. Czasowe wykonywanie usługi może wiązać się z obowiązkiem uzyskania koncesji, zezwolenia, wpisu do rejestru działalności regulowanej, certyfikatu lub inną formą reglamentacji, o ile przepisy ustaw odrębnych nakładają taki obowiązek ze względu na porządek publiczny, bezpieczeństwo publiczne, bezpieczeństwo państwa, zdrowie publiczne lub ochronę środowiska naturalnego. Usługodawca z państwa członkowskiego może świadczyć usługi samodzielnie lub łącznie z innymi usługodawcami z państwa członkowskiego, a odstępstwo od tej zasady może nastąpić w odrębnych ustawach i jest dopuszczalne wyłącznie w celu określonym przez ustawę. Na usługodawcy ciążą obowiązki informacyjne wynikające z ustawy.

Osoby zagraniczne, inne niż przedsiębiorca z państwa członkowskiego, mogą świadczyć usługi na terytorium RP na zasadach określonych w wiążących Rzecz- 
pospolitą Polską umowach międzynarodowych lub - w braku takich umów - na zasadzie wzajemności.

\section{Podsumowanie}

Wprowadzone Konstytucją Biznesu zmiany normatywne w krajowym porządku prawnym w obszarze tworzącym organizacyjnoprawne warunki dla inwestycji zagranicznych na terytorium RP, poprzez przejrzystość i spójność regulacyjną, powinny przyczynić się do zmniejszenia barier wejścia kapitału zagranicznego na polski rynek. Polski ustawodawca wdraża w tym zakresie unijną dyrektywę usługową, a stworzone warunki prawne mają sprzyjać mobilności kapitału oraz intensyfikacji współpracy gospodarczej z przedsiębiorcami zagranicznymi. Przeprowadzona w ostatnim czasie gruntowna reforma polskiego prawa gospodarczego, dokonywana w celu poprawy sytuacji prawnogospodarczej przedsiębiorcy oraz ułatwienia relacji przedsiębiorca-państwo, powinna również wpłynąć na zwiększenie atrakcyjności rynku polskiego dla inwestorów zagranicznych.

\section{Bibliografia}

Begg, D., Vernasca, G., Fischer, S., Dornbusch, R. (2014). Makroekonomia. Warszawa: PWE. Budnikowski, A. (2017). Ekonomia międzynarodowa. Warszawa: PWE.

Burda, M. i Wyplosz, Ch. (2013). Makroekonomia. Podręcznik europejski. Warszawa: PWE. Dyrektywa 2006/123/WE Parlamentu Europejskiego i Rady z dnia 12 grudnia 2006 r. dotycząca usług na rynku wewnętrznym (Dz.Urz. UE L 276 z 27.12.2006).

Hejduk, I.K. i Bakalarczyk, S. (red.). (2013). Global Economics: Past, Present \& Future. Warszawa: Difin.

Kotyński, J. (red.). (2005). Globalizacja i integracja europejska: szanse i zagrożenia dla polskiej gospodarki. Warszawa: PWE.

Mankiw, N.G. i Taylor, M. (2016). Makroekonomia. Warszawa: PWE.

Nowak, A.Z. (2015). W: A.Z. Nowak, T. Zalega (red.), Makroekonomia. Warszawa: PWE.

Nowak, A.Z. (2017). Globalizacja jako makroekonomiczny megatrend. W: A.Z. Nowak, K. Ryć (red.), Polityka w regionach $w$ warunkach globalizacji. Warszawa: Wydawnictwo Naukowe Wydziału Zarządzania UW.

Nowak, A.Z. (2017). Kryzysy a finansyzacja gospodarki światowej. W: A.Z. Nowak, K. Ryć (red.), Polityka $w$ regionach $w$ warunkach globalizacji. Warszawa: Wydawnictwo Naukowe Wydziału Zarządzania UW.

Orłowska, R. i Żołądkiewicz, K. (2012). Globalizacja i regionalizacja w gospodarce światowej. Warszawa: PWE. 
Ustawa z dnia 15 września 2000 r. - Kodeks spółek handlowych (t.j. Dz.U. 2017, poz. 1577 z późn. zm.).

Ustawa z dnia 2 lipca 2004 r. o swobodzie działalności gospodarczej (t.j. Dz.U. 2017, poz. $2168 \mathrm{z}$ późn. zm.).

Ustawa z dnia 20 sierpnia 1997 r. o Krajowym Rejestrze Sądowym (t.j. Dz.U. 2018, poz. 986 z późn. zm.).

Ustawa z dnia 24 marca 1920 r. o nabywaniu nieruchomości przez cudzoziemców (t.j. Dz.U. 2017, poz. 2278).

Ustawa z dnia 4 marca 2010 r. o świadczeniu usług na terytorium Rzeczypospolitej Polskiej (t.j. Dz.U. 2016, poz. 893 z późn. zm.).

Ustawa z dnia 6 lipca 1982 r. o zasadach prowadzenia na terytorium Polskiej Rzeczypospolitej Ludowej działalności gospodarczej w zakresie drobnej wytwórczości przez zagraniczne osoby prawne i fizyczne (t.j. Dz.U. z 1989 r., poz. 27 z późn. zm.).

Ustawa z dnia 6 marca 2018 r. - Prawo przedsiębiorców (Dz.U. 2018, poz. 646).

Ustawa z dnia 6 marca 2018 r. - Przepisy wprowadzające ustawę - Prawo przedsiębiorców oraz inne ustawy dotyczace działalności gospodarczej (Dz.U. 2018, poz. 650).

Ustawa z dnia 6 marca 2018 r. o Centralnej Ewidencji i Informacji o Działalności Gospodarczej i Punkcie Informacji dla Przedsiębiorcy (Dz.U. 2018, poz. 647 z późn. zm.).

Ustawa z dnia 6 marca 2018 r. o Rzeczniku Małych i Średnich Przedsiębiorców (Dz.U. 2018, poz. 648).

Ustawa z dnia 6 marca 2018 r. o zasadach uczestnictwa przedsiębiorców zagranicznych i innych osób zagranicznych w obrocie gospodarczym na terytorium Rzeczypospolitej Polskiej (Dz.U. 2018, poz. 649 z późn. zm.). 